\title{
Quality characteristics of Yanggaeng with extracts and powder of roasted coffee ground residue
}

\author{
Byeong-Guk Kim, La Young Park, Shin-Ho Lee* \\ Department of Food Science and Technology, Catholic University of Daegu, Gyeongsan 38430, Korea
}

\section{커피박 추출물 및 분말 첨가 양갱의 품질 특성}

\author{
김병국 · 박나영 · 이신호* \\ 대구가톨릭대학교 식품공학과
}

\begin{abstract}
Quality characteristics of Yanggaeng prepared with water extract (CRE) and powder (CRP) of roasted coffee ground (CR) were investigated. Total polyphenol content and DPPH raidcal scavenging ability of water extract of CRE were $13.52 \mathrm{~g} / \mathrm{mL}$ and $78.75 \%$, respectively. The $\mathrm{pH}$ ranges of Yanggaeng prepared with CRE (CREY) and CRP (CRPY) were 7.10 7.29 and 6.95 7.15, respectively. The DPPH radical scavenging activities of CREY containing 0.1 1.0\% CRE showed 8.77 43.10\% and CRPY containing 0.1 1.0\% CRP showed 5.28 14.92\%. The total polyphenol contents and DPPH radical scavenging activity of CREY and CRPY increased significantly with increasing CRE and CRP concentrations $(\mathbf{p}<0.05)$. Sensory evaluation which includes taste, flavor, texture, and overall acceptability of CREY and CRPY were higher than that of control. The overall acceptability showed the highest levels in Yanggaeng containing $0.5 \%$ CRE and containing $0.3 \%$ CRP. These results indicate the potential use of roasted coffee ground residue as a valuable resource for development of side menu in coffee restaurants.
\end{abstract}

Key words : roasted coffee ground residue, Yanggaeng, quality characteristic, antioxidative activity

\section{서 론}

현재 커피 전문점의 증가로 일상생활에 때와 장소를 불 문하고 기호에 맞게 다양한 형태의 커피를 쉽게 접할 수 있을 만큼 커피산업은 급성장세를 유지하고 있다. 우리나 라의 커피 소비량은 일년에 평균 일인당 $5 \sim 10 \mathrm{~kg}(1)$ 로, 연간 $10 \%$ 의 꾸준한 성장세를 보이고 있다(2). 이러한 커피 전문 점의 증가는 에스프레소 형태의 커피소비가 증가(3)하고 있음을 의미한다. 커피 소비가 증가함에 따라 에스프레소 를 제조한 후 부산물로 생성되는 커피박의 처리 문제가 대두될 것으로 판단된다. 커피박은 커피 열수 추출물(에스 프레소) 제조과정 중 생기는 부산물로 $1 \mathrm{~kg}$ 의 커피 열수

*Corresponding author. E-mail : leesh@cu.ac.kr

Phone : 82-53-850-3217, Fax : 82-53-850-3217

Received 30 October 2015; Revised 4 February 2016; Accepted 17 February 2016.

Copyright (c) The Korean Society of Food Preservation. All rights reserved.
추출물 당 약 $0.91 \mathrm{~kg}$ 이 생성되고 있다(4). 전국 커피전문점 에서 생성되는 커피박이 그대로 폐기처리 된다는 사실은 환경오염은 물론 자원의 낭비를 초래하는 결과를 낳을 수 있다. 현재 커피박은 일부 사료로 사용되고 있으나 대부분 폐기물로 처리되고 있으며, 일부 비누, 방향제, 비료 등으로 제조하거나 바이오디젤원료(2), 폐수정화처리(1) 등에 이 용되고 있어 재활용 비율은 극히 저조하며 특히, 식품자원 으로의 재활용이나 이에 관한 연구 역시 매우 미미한 상태 이다. 커피박에는 단백질 $10 \%$, 조섬유 $23 \%$, 조지방 $6 \%$ 정도의 영양성분을 함유하고 있으며(5), 커피 원두에 함유 된 tocopherol, chlorogenic acid와 같은 폴리페놀 화합물과 커피를 볶는 과정에서 maillard 반응으로 형성된 melanoidin 이 잔존하고 있어 항산화 활성을 가진다는 연구결과(6)가 보고되어 식자원이나 항산화제로서의 이용 가능성이 충분 히 있는 부산물이라 할 수 있다. 최근 커피박을 이용한 식품 학적 연구로는 간고등어(7), 초콜릿(8), 쿠기(9) 등이 보고되 고 있다.

양갱은 단묵 또는 갱이라고 하여 우리나라 고유의 한과 
중 하나로서 전통적으로 팥, 한천, 설탕을 주원료로 제조하 며, 색과 향이 다채로워서 잔치음식 또는 후식으로 이용되 었으나(10), 현재 기호식품 혹은 등산, 운동과 같은 신체활 동 시 에너지 보충용으로 이용되고 있고, 그 수요가 꾸준히 증가하고 있다(11). 최근에는 인삼, 딸기, 유자, 밤, 고구마 등이나 여러 향미를 첨가한 제품이나 기능성을 부각시켜 연근과 오미자(12), 녹차(13), 냉동송이(14), 홍화씨(15), 파 프리카 $(16,17)$ 등 다양한 기능성 부재료 첨가에 관한 연구 가 보고되고 있다.

본 연구는 커피전문점에서 다량 발생하는 영양성분과 기능성 성분이 잔존하는 커피박을 이용하여 커피 전문점의 사이드 메뉴 개발 가능성을 검토하기 위해 커피박 분말과 커피박 추출물을 첨가한 양갱의 품질특성을 비교하였다.

\section{재료 및 방법}

\section{실험재료}

본 실험에 사용된 커피박(콜롬비아)은 대구.경북지역의 대형 커피 프랜차이즈 매장에서 당일 수집하여 아이스박스 를 이용 저온상태로 운반하여 실험에 사용하였으며, 커피 박과 동일한 브랜드의 커피원두 분말을 구입하여 혼합한 후 대조구로 사용하였다. 커피 원두 및 커피박 열수 추출물 은 물과 1:10의 비율로 혼합한 후 autoclave(JSAC-100, JS Research Inc., Gongju, Korea)를 이용하여 $121^{\circ} \mathrm{C}$ 에서 15 분 동안 추출하여 여과한 후 농축하여 실험에 사용하였다. 커 피박 분말은 autoclave를 이용하여 $121{ }^{\circ} \mathrm{C}$ 에서 15 분간 멸균 하고 냉풍건조기(JJ-10002, Junjin E\&C, Gyeongsan, Korea) 로 건조하였다. 모든 시료는 $-80^{\circ} \mathrm{C}$ 심온 냉동고(NU-6518G, NuAire, Plymouth, MN, USA)에 보관하면서 사용하였다. 양갱 제조에 사용된 앙금(Daedoo Foods, Seoul, Korea), 설 탕(CJ, Seoul, Korea)과 분말한천(Fine Agar, Seongnam, Korea)은 대형마트에서 구입하여 사용하였다.

\section{총 폴리페놀 함량}

총 폴리페놀 함량은 Singleton 등(18)의 방법에 따라 시료 $10 \mathrm{~g}$ 에 $95 \%$ 에탄올 $40 \mathrm{~mL}$ 를 넣은 후 homogenizer(Nissei, Nihonseiki Kaisha Ltd., Tokyo, Japan)로 균질화(10,000 rpm, 2분)한 다음 원심분리기(Centrifuge 5810R, eppendorf, Hamburg, Germany)로 원심분리 $(2,500 \times \mathrm{g}, 15$ 분 $)$ 하여 얻어 진 상층액 $1 \mathrm{~mL}$ 에 $0.2 \mathrm{~N}$ Folin-Ciocalteu's reagent (SigmaAldrich Co., St. Louis, MO, USA) $1 \mathrm{~mL}$ 를 가하여 실온에서 3 분간 반응시킨 후 $7.5 \% \mathrm{Na}_{2} \mathrm{CO}_{3}$ (Sigma-Aldrich Co.) $1 \mathrm{~mL}$ 를 가하여 암소에서 1 시간 동안 방치한 후 분광광도계 (Ultrospec 1000, Pharmacia Biotech, Cambridge, UK)를 사용 하여 $765 \mathrm{~nm}$ 에서 흡광도를 측정하였다. 총 폴리페놀 함량 은 gallic acid(Sigma-Aldrich Co.)를 표준물질로 하여 얻은
표준곡선에 의하여 산출하였다.

\section{$\mathrm{DPPH}$ 라디칼 소거능}

DPPH(a-a-diphenyl- $\beta$-picrylhydrazyl, Sigma-Aldrich Co.) 라디칼 소거능은 Blois(19)의 방법을 변형하여 추출된 시료 용액 $0.4 \mathrm{~mL}$ 에 $0.4 \mathrm{mM} \mathrm{DPPH}$ 에탄올 용액 $0.8 \mathrm{~mL}$ 를 가하여 진탕 혼합하고 상온에서 10 분간 방치 후 $525 \mathrm{~nm}$ 에서 흡광 도를 측정하였으며 계산식, DPPH radical scavenging activity $(\%)=[1-(\mathrm{OD}$ of sample/OD of control) $] \times 100$ 에 의하 여 활성을 산출하였다.

\section{양갱의 제조}

양갱 제조시 사용한 앙금은 커피박과 커피추출물 사용에 따른 양갱 색상의 변화에 따른 기호성 그리고 커피박 또는 열수추출물의 적정 첨가농도를 구명하기 위하여 백앙금을 사용하였다. 커피박 열수 추출물 $(2 \%, \mathrm{w} / \mathrm{v})$ 은 양갱 제조시 첨가되는 물에 최종 고형분 함량이 $0 \%, 0.1 \%, 0.3 \%, 0.5 \%$, $1.0 \%$ 의 비율이 되도록 적정 희석하여 사용하였다. 커피박 분말 첨가구는 커피박 분말을 앙금의 $0.1 \%, 0.3 \%, 0.5 \%$, $1.0 \%$ 의 비율로 첨가하였으며, 한천, 설탕과 물은 처리구별 동량 사용하였다. 각각의 원부재료의 배합비는 Table 1 에 나타내었다.

양갱의 제조는 물 또는 커피박 열수 추출물이 혼합된 물에 한천을 가하여 실온에서 20 분간 방치시킨 후 중불에 서 10 분간 저어주면서 한천가루를 용해시켜 약한 불에서 앙금 또는 커피박 분말과 혼합된 앙금과 설탕을 충분히 혼합한 다음 5 분간 가열과정을 거쳐 일정크기의 stainless 틀 $(20 \mathrm{~cm} \times 15 \mathrm{~cm} \times 10 \mathrm{~cm})$ 에 넣어 2 시간 동안 상온에서 응고 시켰다.

Table 1. Formulation of Yanggaeng containing different type and concentration of roasted coffee ground residue

\begin{tabular}{ccccccccccc}
\hline & \multicolumn{1}{c}{ CREY $^{3}$ Ingredient } & 0 & \multicolumn{4}{c}{ (unit: g) } \\
\cline { 2 - 10 } & & 0.1 & 0.3 & 0.5 & 1.0 & 0.1 & 0.3 & 0.5 & 1.0 \\
\hline Cooked white bean & 600 & 600 & 600 & 600 & 600 & 599.4 & 598.2 & 597 & 594 \\
Agar & 30 & 30 & 30 & 30 & 30 & 30 & 30 & 30 & 30 \\
Sugar & 200 & 200 & 200 & 200 & 200 & 200 & 200 & 200 & 200 \\
CRE $^{1)}(2 \%)$ & 0 & 20 & 60 & 100 & 200 & 0 & 0 & 0 & 0 \\
CRP $^{2)}$ & 0 & 0 & 0 & 0 & 0 & 0.6 & 1.8 & 3 & 6 \\
Water & 400 & 380 & 340 & 300 & 200 & 400 & 400 & 400 & 400 \\
\hline
\end{tabular}

${ }^{1)} \mathrm{CRE}$, Roasted coffee ground residue water extract.

${ }^{2)} \mathrm{CRP}$, Roasted coffee ground residue powder.

${ }^{3}$ CREY, Yanggaeng containing roasted coffee ground residue extract.

${ }^{4} \mathrm{CRPY}$, Yanggaeng containing roasted coffee ground residue powder

$\mathrm{pH}$ $\mathrm{pH}$ 는 Kwak 등(20)의 실험방법에 따라 양갱 $10 \mathrm{~g}$ 에 멸균 
생리식염수 $40 \mathrm{~mL}$ 를 첨가 하여 homogenizer(Nihonseiki Kaisha Ltd.)를 이용하여 균질(10,000 rpm, 2 분) 후, 상기의 원심분리기를 이용 원심분리 $(2,500 \times \mathrm{g}, 15$ 분 $)$ 하여 상층액 $10 \mathrm{~mL}$ 를 채취하여 $\mathrm{pH}$ meter(Orion 410A, Orion Research Inc., Boston, MA, USA)로 측정하였다.

\section{수분 및 당도}

수분 함량은 $105^{\circ} \mathrm{C}$ 상압건조법(21)으로 3회 반복 측정하 였다. 당도는 시료를 증류수로 5 배 희석하여 상기와 동일한 균질기로 균질시킨 다음 원심분리 $(2,500 \times \mathrm{g}, 15$ 분 $)$ 한 후 상 등액을 취하여 당도계(Master-a, Atago Co., Tokyo, Japan)로 3 회 반복 측정하였다(22).

\section{색 도}

양갱 $10 \mathrm{~g}$ 당 $95 \%$ 에탄올 $40 \mathrm{~mL}$ 를 첨가해 homogenizer로 $10,000 \mathrm{rpm}$ 에서 2 분간 균질화한 현탁액의 색도를 측정하였 다. 색도는 색차계(CR-400, Konica Minolta, Tokyo, Japan) 를 사용하여 명도(L), 적색도(a), 황색도(b)를 측정하였으며 각각 3회 반복 측정한 후 평균값으로 나타내었다. 이때 표준 색은 $\mathrm{Y}=86.7, \mathrm{x}=0.3151, \mathrm{y}=0.3213$ 으로 하였으며, $\Delta \mathrm{E}$ value 는 다음의 계산식에 넣어 계산하였다.

$\left.\Delta \mathbb{E}=\quad-L_{t}\right)^{2}+\left(a_{i}-a_{t}\right)^{2}+\left(b_{i}-b_{t}\right)^{2}, \mathbf{i}=$ initial, $\mathbf{t}=$ test

조직감

조직감은 양갱을 일정 크기 $(2 \mathrm{~cm} \times 2 \mathrm{~cm} \times 2 \mathrm{~cm})$ 로 절단하 여 Rheometer(Compac-100П, Sun Scientific Co., Tokyo, Japan)로 경도(hardness), 탄력성(springiness), 응집성 (cohesiveness)을 측정하였다. 측정 조건은 최대 하중 $2 \mathrm{~kg}$, probe distance $10.00 \mathrm{~mm}$, table speed $60 \mathrm{~mm} / \mathrm{min}$, distance $50 \%$ 였으며, 모든 시료는 10 회 반복 측정하여 평균값을 나 타내었다.

\section{관능검사}

관능검사는 식품공학을 전공하는 남녀대학생 30 명을 대 상으로 각각의 시료를 용기에 담아 제시하였으며 검사방법 과 평가특성을 교육시킨 후 실시하였다. 검사 항목은 색 (color), 맛(taste), 향(flavor), 조직감(texture), 종합적 기호도 (overall acceptability)에 대하여 5점 채점법(1점, 아주 나쁘 다; 3점, 보통; 5점, 아주 좋다)으로 평가하였다.

\section{통계분석}

각 시료간의 유의성은 SPSS system(Statistical Package for Social Sciences, IBM SPSS Inc., Chicago, IL, USA) software package(version 19.0)을 이용, $\mathrm{p}<0.05$ 수준으로 Duncan's multiple range test에 의하여 검증하였다.

\section{결과 및 고찰}

커피원두와 커피박 열수 추출물의 총 폴리페놀 함량 및 $\mathrm{DPPH}$ 라디칼 소거능

커피원두 및 커피박 열수 추출물의 총 폴리페놀 함량 및 DPPH 라디칼 소거능은 Table 2에 나타내었다. 고형분 함량을 $0.1 \mathrm{mg} / \mathrm{mL}$ 로 조정한 원두와 커피박 추출물의 총 폴리페놀 함량은, 각각 $16.65,13.52 \mathrm{\mu g} / \mathrm{mL}$ 로 나타내어 커피 박 열수 추출물이 원두 열수 추출물보다 낮았으나 상당량의 폴리페놀이 커피박에 잔존 하는 경향을 나타내었다. 커피 의 항산화능은 주로 폴리페놀 화합물에 기인하는 것으로, 특히 chlorogenic acid, caffeic acid, ferulic acid, p-coumaric acid, proanthocyanidins 등이 항산화능과 관련이 있는 것으 로 알려져 있다(23).

고형분 함량을 $1 \mathrm{mg} / \mathrm{mL}$ 농도로 조정한 원두 및 커피박 추출물의 DPPH 라디칼 소거능은 각각 $88.36 \%, 78.75 \%$ 를 나타내어 커피박은 에스프레소로 추출한 후임에도 불구하 고 원두와 유사한 항산화 활성을 유지하고 있는 것으로 판단된다.

Table 2. Total polyphenol content and DPPH radical scavenging ability of extracts from roasted coffee ground and roasted coffee ground residue

\begin{tabular}{ccc}
\hline Samples $^{1)}$ & $\begin{array}{c}\text { Total polyphenol content } \\
(\mu \mathrm{g} / \mathrm{mL})\end{array}$ & $\begin{array}{c}\text { DPPH radical scavenging } \\
\text { activity }(\%)\end{array}$ \\
\hline CG & $16.55 \pm 0.35^{2) b 3)}$ & $88.36 \pm 0.50^{\mathrm{b}}$ \\
$\mathrm{CR}$ & $13.52 \pm 0.76^{\mathrm{a}}$ & $78.75 \pm 0.61^{\mathrm{a}}$ \\
\hline
\end{tabular}

${ }^{1)} \mathrm{CG}$, Roasted coffee ground; CR, Roasted coffee ground residue.

${ }^{2)}$ Each value was expressed as the mean \pm SD of triplicate assays.

${ }^{3) a-b}$ Means with different superscripts within the CG and CR are indicate significant differences $(p<0.05)$.

\section{$\mathrm{pH}$, 수분함량 및 당도의 변화}

커피박 열수 추출물과 커피박을 첨가한 양갱의 $\mathrm{pH}$, 수분 함량 및 당도를 측정한 결과는 Table 3에 나타내었다. 대조 구의 $\mathrm{pH}$ 는 7.42 였으나 커피박 열수 추출물 첨가 양갱 (CREY)은 7.10 7.29의 범위를 나타내었고, 커피박 분말 첨 가 양갱(CRPY)은 6.95 7.15의 범위를 나타내었다.

수분함량은 대조구가 $36.64 \%$ 로 가장 낮았으며, CREY는 37.88 38.92\%으로 첨가농도에 따라 증가하는 경향을 나타 내었으며, CRPY는 39.30 40.00\%로 대조구에 비해 유의적 으로 높았으나 첨가 농도에 따른 뚜렷한 차이는 관찰할 수 없었다. 이러한 결과는 홍화씨 분말(15), 파프리카 분말 (16) 첨가 양갱의 보고와 유사하였다.

$\mathrm{CREY}$ 와 $\mathrm{CRPY}$ 의 당도는 각각 $11.30 \sim 11.75{ }^{\circ} \mathrm{Brix}$, 11.20 11.70 ${ }^{\circ} \mathrm{Brix}$ 의 범위를 나타내어 대조구 $\left(11.90{ }^{\circ} \mathrm{Brix}\right)$ 에 비해 유의적으로 낮았으며, 첨가농도가 증가할수록 뚜 렷하게 감소하였다 $(\mathrm{p}<0.05)$. 이는 양갱에 첨가되는 고형분 에 의한 당분의 희석효과 및 커피박 첨가량에 비례하여 
단맛의 주체가 되는 앙금의 첨가량 감소에 기인된 것으로 판단된다.

Table 3. Changes in $\mathrm{pH}$, water and sugar contents of Yanggaeng containing different type and concentration of roasted coffee ground residue

\begin{tabular}{ccccc}
\hline \multicolumn{2}{c}{ Samples ${ }^{1}$} & $\mathrm{pH}$ & $\begin{array}{c}\text { Water contents } \\
(\%)\end{array}$ & $\begin{array}{c}\text { Sugar contents } \\
\left({ }^{\circ} \mathrm{Brix}\right)\end{array}$ \\
\hline \multicolumn{6}{c}{ Control } & $7.42 \pm 0.06^{2) \mathrm{D} 3)}$ & $36.64 \pm 0.36^{\mathrm{aA}}$ & $11.90 \pm 0.10^{\mathrm{CE}}$ \\
\hline \multirow{4}{*}{$\mathrm{C} E Y$} & 0.1 & $7.29 \pm 0.01^{\mathrm{d}}$ & $37.88 \pm 0.55^{\mathrm{b}}$ & $11.75 \pm 0.00^{\mathrm{b}}$ \\
& 0.3 & $7.17 \pm 0.02^{\mathrm{C}}$ & $37.46 \pm 0.25^{\mathrm{a}}$ & $11.70 \pm 0.00^{\mathrm{b}}$ \\
& 0.5 & $7.10 \pm 0.00^{\mathrm{b}}$ & $38.49 \pm 0.68^{\mathrm{C}}$ & $11.35 \pm 0.02^{\mathrm{a}}$ \\
& 1 & $7.10 \pm 0.01^{\mathrm{a}}$ & $38.92 \pm 0.56^{\mathrm{C}}$ & $11.30 \pm 0.00^{\mathrm{a}}$ \\
\hline \multirow{4}{*}{ CRPY } & 0.1 & $7.15 \pm 0.02^{\mathrm{C}}$ & $40.00 \pm 0.46^{\mathrm{B}}$ & $11.70 \pm 0.00^{\mathrm{D}}$ \\
& 0.3 & $7.12 \pm 0.00^{\mathrm{C}}$ & $39.70 \pm 0.40^{\mathrm{B}}$ & $11.57 \pm 0.06^{\mathrm{C}}$ \\
& 0.5 & $7.03 \pm 0.01^{\mathrm{B}}$ & $39.43 \pm 0.51^{\mathrm{B}}$ & $11.40 \pm 0.00^{\mathrm{B}}$ \\
& 1 & $6.95 \pm 0.05^{\mathrm{A}}$ & $39.30 \pm 0.55^{\mathrm{B}}$ & $11.20 \pm 0.00^{\mathrm{A}}$ \\
\hline
\end{tabular}

${ }^{1} \mathrm{CREY}$, Yanggaeng containing roasted coffee ground residue extract; CRPY, Yanggaeng containing roasted coffee ground residue powder.

${ }^{2)}$ Each value was expressed as the mean \pm SD of triplicate assays.

3)a-e,AE Means with different superscripts within the CREY and CRPY are indicate significant differences $(\mathrm{p}<0.05)$.

색 도

커피박 열수 추출물 및 분말의 첨가량을 달리하여 제조 한 양갱의 색도를 측정한 결과는 Table 4에 나타내었다. 명도를 나타내는 L(lightness)값은 대조구가 43.18로 가장 높았다. CRE 0.1, 0.3, 0.5 및 $1.0 \%$ 를 첨가한 양갱은 각각 $39.39,30.81,29.55,26.55$ 로 커피박 열수 추출물의 첨가량 이 증가할수록 유의적으로 낮았다 $(\mathrm{p}<0.05) . \mathrm{CRP}$ 를 첨가한 양갱도 커피박 열수 추출물 첨가한 양갱과 유사하게 첨가량 이 증가할수록 명도는 감소하였다. 이는 Park 등(24)의 흑마 늘 페이스트 첨가 양갱의 연구결과와 같이 커피의 짙은색에 의해 양갱의 색이 점점 어두워진 것으로 판단된다. 적색도

Table 4. The color changes of Yanggaeng containing different type and concentration of roasted coffee ground residue

\begin{tabular}{|c|c|c|c|c|c|}
\hline \multicolumn{2}{|c|}{ Samples ${ }^{1)}$} & Lightness (L) & Redness (a) & Yellowness (b) & $\Delta \mathrm{E}$ \\
\hline \multicolumn{2}{|c|}{ Control } & $43.18 \pm 0.04^{2) \mathrm{eE} 33}$ & $0.46 \pm 0.02^{\mathrm{aA}}$ & $4.89 \pm 0.01^{\mathrm{bE}}$ & - \\
\hline \multirow{4}{*}{ CREY } & 0.1 & $39.39 \pm 0.01^{\mathrm{d}}$ & $1.11 \pm 0.03^{\mathrm{b}}$ & $5.81 \pm 0.02^{\mathrm{e}}$ & $3.95 \pm 0.00$ \\
\hline & 0.3 & $30.81 \pm 0.01^{\mathrm{c}}$ & $1.77 \pm 0.02^{\mathrm{d}}$ & $5.78 \pm 0.02^{\mathrm{d}}$ & $12.47 \pm 0.01$ \\
\hline & 0.5 & $29.55 \pm 0.02^{\mathrm{b}}$ & $1.60 \pm 0.05^{\mathrm{c}}$ & $5.30 \pm 0.01^{\mathrm{c}}$ & $13.68 \pm 0.02$ \\
\hline & 1 & $26.55 \pm 0.01^{\mathrm{a}}$ & $2.08 \pm 0.06^{e}$ & $4.49 \pm 0.02^{\mathrm{a}}$ & $16.71 \pm 0.00$ \\
\hline \multirow{4}{*}{ CRPY } & 0.1 & $36.79 \pm 0.12^{\mathrm{D} 2)}$ & $0.53 \pm 0.46^{\mathrm{B}}$ & $4.52 \pm 0.02^{\mathrm{D}}$ & $6.41 \pm 0.12$ \\
\hline & 0.3 & $36.53 \pm 0.01^{\mathrm{C}}$ & $0.97 \pm 0.03^{\mathrm{C}}$ & $3.92 \pm 0.02^{\mathrm{C}}$ & $6.74 \pm 0.01$ \\
\hline & 0.5 & $31.23 \pm 0.01^{\mathrm{B}}$ & $1.09 \pm 0.04^{\mathrm{D}}$ & $3.38 \pm 0.02^{\mathrm{B}}$ & $12.06 \pm 0.01$ \\
\hline & 1 & $28.56 \pm 0.01^{\mathrm{A}}$ & $1.33 \pm 0.01^{\mathrm{E}}$ & $2.25 \pm 0.00^{\mathrm{A}}$ & $14.88 \pm 0.01$ \\
\hline
\end{tabular}

${ }^{1 \mathrm{CREY}}$, Yanggaeng containing roasted coffee ground residue extract; CRPY, Yanggaeng containing roasted coffee ground residue powder.

${ }^{2)}$ Each value was expressed as the mean $\pm \mathrm{SD} \quad(\mathrm{n}=30)$.

3)a-e,AC Means with different superscripts within the CREY and CRPY are indicate significant differences $(\mathrm{p}<0.05)$.
를 나타내는 a(redness)값을 조사한 결과, 대조구는 0.46 으 로 가장 낮은 값을 나타내었고, CREY는 1.11 2.08 범위의 값을 나타내어 CRE 첨가 농도가 증가할수록 적색도는 유의 적으로 증가하였다 $(\mathrm{p}<0.05)$. CRPY도 $0.53 ~ 1.33$ 의 범위 값 을 나타내어 커피박 분말 첨가량에 비례하여 a 값은 증가하 였는데, $\mathrm{CRE}$ 동일 농도구와 비교하였을 경우, $\mathrm{CRPY}$ 가 a값 의 증가율이 낮았다. 이는 커피박 분말이 물에 혼합되면서 커피박의 갈색 성분이 충분히 용출되지 않았기 때문인 것으 로 사료된다. 황색도를 나타내는 b(yellowness)값은, $\mathrm{CRE}$ $0.1 \%$ 첨가 양갱이 5.81 로 가장 높았으며, 다음은 $\mathrm{CRE} 0.3 \%$ 첨가구 > CRE $0.5 \%$ 첨가구 순이었으며, $\mathrm{CRE} 1.0 \%$ 첨가구 는 4.49로 대조구보다 낮았다. CRPY는 4.52 2.25의 값을 나타내어 커피박 분말을 첨가한 양갱은 대조구보다 $\mathrm{b}$ 값이 낮았으며, 커피박 분말 첨가량이 증가할수록 $\mathrm{b}$ 값은 감소하 였다.

조직감

$\mathrm{CREY}$ 와 $\mathrm{CRPY}$ 의 조직감 측정 결과는 Table 5 에서 보는 바와 같이 경도는 대조구가 $5.26 \mathrm{~g} / \mathrm{cm}^{2}$ (이후 단위생략)로 가장 낮았으며, $\mathrm{CREY}$ 는 5.95 6.49의 범위로 농도가 증가할 수록 증가하였으나, $0.3 \%$ 이상에서 첨가농도에 따른 유의 적 차이는 나타나지 않았다(p<0.05). 이는 $\mathrm{Kim}$ 등(25)의 $\mathrm{pH}$ 가 낮을수록 양갱의 주재료인 팥과 전분 겔의 견고성이 증가하였다고 보고한 결과와 같이 커피박 추출물의 낮은 $\mathrm{pH}$ 때문에 CRE 첨가 농도가 증가할수록 양갱의 경도는 증가하는 것으로 판단된다. $\mathrm{CRPY}$ 의 경도는 대조구보다 높았으며, 첨가농도 $0.3 \%$ 까지는 증가하다가 $0.5 \%$ 이상부 터는 감소하였다. 탄력성(springiness)은 대조구 $421.02 \%$ 에 비해 CREY는 첨가농도 0.1 0.5\%까지 438.38\% 451.13\% 로 증가하였으나 $1.0 \%$ 첨가구는 감소하였으며, CRPY는 첨가농도 $0.3 \%$ 까지 증가하다가 $0.5 \%$ 첨가부터 감소하는

Table 5. Textural characteristics in Yanggaeng containing different type and concentration of roasted coffee ground residue

\begin{tabular}{ccccc}
\hline Samples ${ }^{1}$ & $\begin{array}{c}\text { Hardness } \\
\left(\mathrm{g} / \mathrm{cm}^{2}\right)\end{array}$ & $\begin{array}{c}\text { Springiness } \\
(\%)\end{array}$ & $\begin{array}{c}\text { Cohesiveness } \\
(\%)\end{array}$ \\
\hline \multicolumn{6}{c}{ Control } & $5.26 \pm 0.41^{2 \mathrm{aA} 3)}$ & $421.02 \pm 51.80^{\mathrm{aAB}}$ & $55.11 \pm 2.74^{\mathrm{dA}}$ \\
\hline \multirow{4}{*}{$\mathrm{C} E Y$} & 0.1 & $5.95 \pm 0.63^{\mathrm{ab}}$ & $438.38 \pm 11.42^{\mathrm{a}}$ & $47.91 \pm 4.75^{\mathrm{c}}$ \\
& 0.3 & $6.34 \pm 0.21^{\mathrm{b}}$ & $435.36 \pm 14.00^{\mathrm{a}}$ & $49.00 \pm 4.46^{\mathrm{c}}$ \\
& 0.5 & $6.25 \pm 0.81^{\mathrm{b}}$ & $451.13 \pm 57.69^{\mathrm{a}}$ & $42.15 \pm 3.43^{\mathrm{b}}$ \\
& 1 & $6.49 \pm 0.84^{\mathrm{b}}$ & $392.76 \pm 52.92^{\mathrm{a}}$ & $40.21 \pm 3.99^{\mathrm{a}}$ \\
\hline \multirow{4}{*}{ CRPY } & 0.1 & $6.32 \pm 0.25^{\mathrm{B}}$ & $450.97 \pm 50.13^{\mathrm{B}}$ & $56.65 \pm 2.22^{\mathrm{A}}$ \\
& 0.3 & $6.59 \pm 0.53^{\mathrm{B}}$ & $496.02 \pm 41.23^{\mathrm{C}}$ & $55.27 \pm 6.64^{\mathrm{A}}$ \\
& 0.5 & $6.10 \pm 0.50^{\mathrm{B}}$ & $386.75 \pm 30.82^{\mathrm{B}}$ & $53.01 \pm 7.75^{\mathrm{A}}$ \\
& 1 & $6.00 \pm 0.40^{\mathrm{B}}$ & $362.31 \pm 45.22^{\mathrm{A}}$ & $51.81 \pm 5.06^{\mathrm{A}}$ \\
\hline
\end{tabular}

${ }^{10} \mathrm{CREY}$, Yanggaeng containing roasted coffee ground residue extract; CRPY, Yanggaeng containing roasted coffee ground residue powder.

${ }^{2)}$ Each value was expressed as the mean $\pm S D$ of triplicate assays.

${ }^{3) a-c, A-C}$ Means with different superscripts within the CREY and CRPY are indicate significant differences $(\mathrm{p}<0.05)$. 
경향을 나타내었다. 응집성은 $\mathrm{CRE}$ 는 농도가 증가함에 따 라 대조구에 비해 감소하였으나 CRPY는 $0.3 \%$ 첨가구까지 대조구와 유사하였다. 이는 양갱 제조에 사용되는 물의 양 에 비해 과량 첨가한 커피박 분말이 완전히 수화되지 않아 양갱성분과 충분한 결합을 형성하지 못하여 부스러지기 쉬운 조직을 형성하였기 때문인 것으로 판단된다(26). 양갱 제조시 커피박 추출물과 커피박 분말의 첨가량은 $0.3 \%$ 가 가장 효과적일 것으로 판단된다.

\section{총 폴리페놀 함량 및 DPPH 라디칼 소거능}

시험 용액을 10 배 희석하여 측정한 $\mathrm{CREY}$ 및 $\mathrm{CRPY}$ 의 총 폴리페놀 함량은 Fig. 1에 나타내었다. 대조구는 8.49 $\mathrm{\mu g} / \mathrm{mL}, \mathrm{CRE}$ 와 CRP 첨가농도( $0.1,0.3,0.5$ 및 $1.0 \%)$ 에 따라 CREY는 15.88, 32.16, 41.12 및 $66.19 \mu \mathrm{gg} / \mathrm{mL}$ 로 증가하였으 며, CRPY는 12.09, 15.87, 20.75 및 $23.80 \mu \mathrm{g} / \mathrm{mL}$ 을 나타내어 첨가량에 비례하여 유의적으로 증가하였다 $(\mathrm{p}<0.05)$.

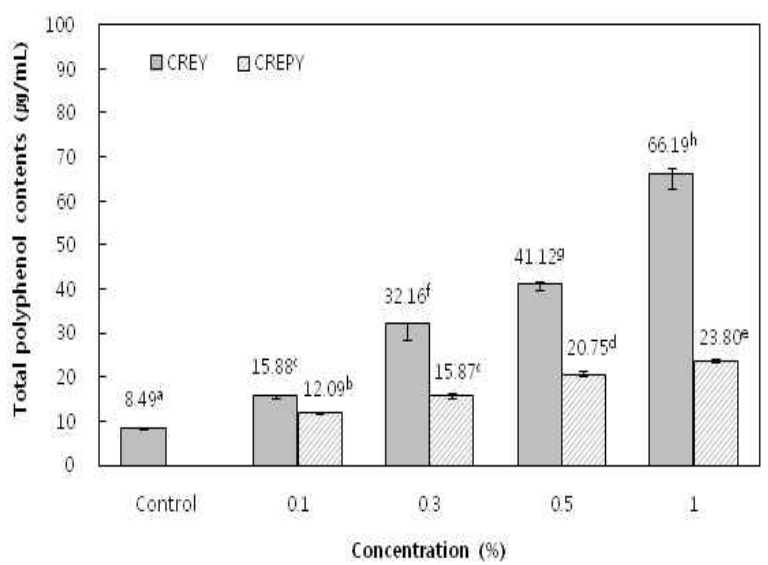

Fig. 1. Total polyphenol contents of Yanggaeng containing different type and concentration of roasted coffee ground residue.

CREY, Yanggaeng containing roasted coffee ground residue extract; CRPY, Yanggaeng containing roasted coffee ground residue powder.

Each value was expressed as the mean $\pm \mathrm{SD}$ of triplicate assays

${ }^{a-h}$ Means with different superscripts within a bar are indicate significant differences $(\mathrm{p}<0.05)$.

$\mathrm{CREY}$ 및 $\mathrm{CRPY}$ 의 DPPH 라디칼 소거능의 변화는 Fig. 2 에 나타내었다. 대조구는 $1.88 \%, \mathrm{CREY}$ 는 첨가농도 $(0.1$, $0.3,0.5$ 및 $1.0 \%$ )에 따라 각각 $8.77,23.02,31.92,43.10 \%$ 을 나타내어 첨가 농도에 비례하여 양갱의 항산화 활성은 유의 적으로 증가하였다(p<0.05). CRPY도 첨가농도 $(0.1,0.3,0.5$ 및 1.0\%)에 따라 5.28 14.92\%의 소거능을 나타내어 대조구 보다 유의적으로 높았으나( $\mathrm{p}<0.05), \mathrm{CREY}$ 에 비해 상대적 으로 낮은 항산화 활성을 나타내었다. 이러한 현상은 일반 초코렛 제조시 커피박 첨가량이 증가할수록 DPPH 라디칼 소거능이 증가하였다는 보고(8)와 유사하였다

커피박 추출물이나 분말의 항산화 활성은 양갱 제조시의 비교적 높은 온도에서도 높은 활성을 유지하는 것으로 나타
나, 커피박은 양갱 제조 시 양갱의 항산화 활성 증진을 위한 소재로 사용이 가능할 것으로 판단된다.

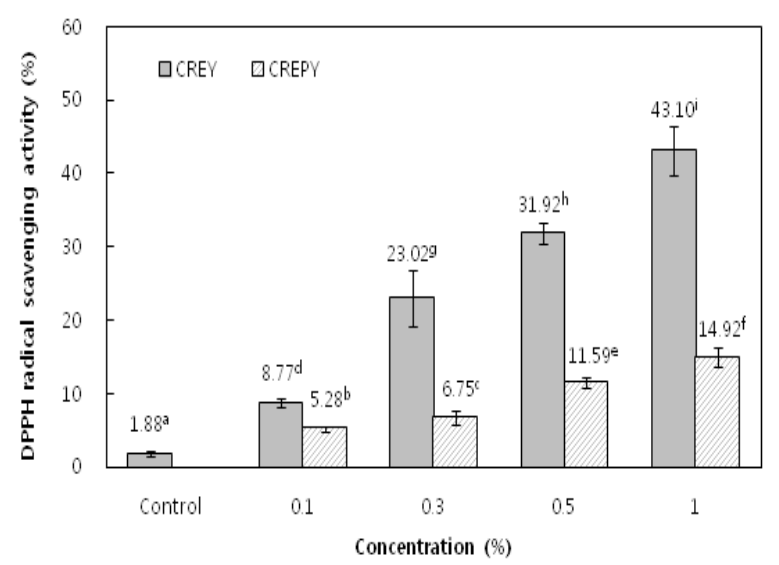

Fig. 2. DPPH radical scavenging activity of Yanggaeng containing different type and concentration of roasted coffee ground residue.

CREY, Yanggaeng containing roasted coffee ground residue extract; CRPY, Yanggaeng containing roasted coffee ground residue powder.

Each value was expressed as the mean \pm SD of triplicate assays.

${ }^{a-1}$ Means with different superscripts within a bar are indicate significant differences $(\mathrm{p}<0.05)$.

관능적 특성

커피박 추출물과 커피박 분말을 첨가한 양갱의 관능적 특성은 Table 6과 같다. 색은 대조구 2.72 에 비해 CRE $0.1 \%$ 와 $0.3 \%$ 첨가한 양갱이 3.56 으로 가장 높은 경향을 나타내 었으며, $\mathrm{CRP}$ 첨가구의 색에 대한 기호도는 대조구에 비해 높았으나 CRE 첨가구에 비해서 다소 낮은 경향을 타나내었 다. 맛의 경우도 커피박 첨가 형태와 상관없이 모든 첨가구 가 대조구보다 높았으며, $\mathrm{CREY}$ 는 $0.5 \%$ 첨가구(4.16)가 가 장 우수하였으며, $\mathrm{CRP}$ 는 $0.5 \%$ 첨가구(3.64)가 우수하였다. 또한, $\mathrm{CREY}$ 는 첨가농도에 따라 3.44 4.16, $\mathrm{CRPY}$ 는 3.16 3.64을 나타내어 모두 3.0 이상의 평가를 받아 커피박 은 소비자의 기호성을 충족시킬 수 있는 좋은 부재료라고 판단된다. 풍미도 $\mathrm{CRE}$ 와 $\mathrm{CRP}$ 를 첨가한 양갱이 모두 대조 구보다 우수하다고 평가되었으며, $\mathrm{CRE} 0.5 \%$ 첨가구는 $4.16, \mathrm{CRP} 0.3 \%$ 첨가구는 3.64 로 각 처리구에서 가장 높았 다. 풍미가 다른 관능적 특성에 비해 높게 평가된 것은 커피 의 향이 양갱의 풍미에 긍정적 영향을 미쳤기 때문인 것으 로 사료되며, $0.5 \%$ 이상의 농도에서는 커피향이 강하여 기호성이 다소 감소하였다. 조직감도 모든 첨가구에서 대 조구보다는 우수하였으나, $\mathrm{CRE}$ 와 CRP $0.3 \%$ 첨가구까지는 각각 조직감에 대한 기호도가 증가하고, 그 이상의 농도에 서는 다소 감소하였다. 종합적 기호도도 $\mathrm{CRE}$ 와 $\mathrm{CRP}$ 첨가 에 의해서 대조구에 비해 모두 향상되었으며, 커피박의 첨 가형태에 따라 $\mathrm{CRE}$ 는 $0.5 \%$ 첨가구가 $4.08, \mathrm{CRP}$ 는 $0.3 \%$ 첨 가구가 3.56 으로 가장 우수하였다. 소비자의 기호성과 항산 화 활성 등 품질특성을 종합적으로 고려하여, 양갱 제조시 $\mathrm{CRE} 0.5 \%, \mathrm{CRP} 0.3 \%$ 를 첨가하는 것이 가장 최적 조건으로 
판단된다.

양갱 제조시 커피박 열수 추출물과 커피박 분말의 이용 은 양갱의 항산화 활성 증진과 기호성 증진이라는 품질개선 효과를 기대할 수 있을 뿐 아니라, 폐기물로 인식되고 있는 커피박을 식품소재로서 재활용한다는 측면에서 의의가 있 다고 판단된다. 양갱은 그 제조법이 간단하고, 다양한 형태 의 제품 제조가 가능하여 매장에서 즉석 제조 및 상품화가 가능하여 커피전문점의 사이드 메뉴로서의 이용이 가능할 것으로 판단된다. 이러한 제품을 상용화하기 위해서는 커 피박을 이용한 양갱의 영양 및 물성학적 품질 개선에 필요 한 광범위한 연구가 선행되어야 할 것으로 사료된다.

Table 6. Sensory properties of Yanggaeng containing different type and concentration of roasted coffee ground residue

\begin{tabular}{|c|c|c|c|c|c|c|}
\hline \multicolumn{2}{|c|}{ Samples ${ }^{1)}$} & lor & te & or & Texture & $\begin{array}{c}\text { Overall } \\
\text { Acceptability }\end{array}$ \\
\hline \multicolumn{2}{|c|}{ ntrol } & & & & $2.84 \pm 0.55^{\mathrm{aA}}$ & $2.80 \pm 0.65^{\mathrm{aA}}$ \\
\hline \multirow{4}{*}{ CREY } & 0.1 & $.56 \pm 1.00^{b}$ & $3.72 \pm 0.68^{\mathrm{bc}}$ & $3.00 \pm 0.50^{b}$ & $3.28 \pm 0.68^{b c}$ & $3.56 \pm 0.51^{b}$ \\
\hline & 0. & $3.56 \pm 1.00^{b}$ & $4.00 \pm 0.50^{c}$ & $3.86 \pm 0.78^{\mathrm{cd}}$ & $3.56 \pm 0.71^{\mathrm{c}}$ & $4.00 \pm 0.50^{c}$ \\
\hline & 0.5 & $3.44 \pm 0.87^{b}$ & $4.16 \pm 0.80^{c}$ & $4.16 \pm 0.80^{\mathrm{d}}$ & $3.36 \pm 0.49^{\text {bc }}$ & $4.08 \pm 0.86^{c}$ \\
\hline & 1 & $.22 \pm 0.72^{\mathrm{ab}}$ & $3.44 \pm 1.12^{\mathrm{ab}}$ & $3.56 \pm 0.87^{c}$ & $3.08 \pm 0.81^{\mathrm{ab}}$ & $3.28 \pm 0.68^{b}$ \\
\hline \multirow{4}{*}{ CRPY } & 0.1 & $3.20 \pm 0.82^{\mathrm{AB}}$ & $3.16 \pm 0.62^{\mathrm{AB}}$ & $3.04 \pm 0.68^{\mathrm{B}}$ & $3.12 \pm 0.53^{\mathrm{A}}$ & $3.12 \pm 0.78^{\mathrm{AB}}$ \\
\hline & 0.3 & $3.36 \pm 0.76^{\mathrm{B}}$ & $3.64 \pm 0.99^{B}$ & $3.64 \pm 0.91^{\mathrm{C}}$ & $3.16 \pm 0.62^{\mathrm{A}}$ & $3.56 \pm 0.51^{\mathrm{C}}$ \\
\hline & 0.5 & $3.12 \pm 0.97^{\mathrm{AB}}$ & $3.20 \pm 0.82^{\mathrm{AB}}$ & $3.36 \pm 0.76^{\mathrm{BC}}$ & $3.00 \pm 0.71^{\mathrm{A}}$ & $3.24 \pm 0.83^{\mathrm{BC}}$ \\
\hline & 1 & $2.96 \pm 0.79^{\mathrm{AB}}$ & $3.21 \pm 0.41^{\mathrm{AB}}$ & $3.48 \pm 0.92^{\mathrm{BC}}$ & $2.88 \pm 0.60^{\mathrm{A}}$ & $3.00 \pm 0.41^{\mathrm{AB}}$ \\
\hline
\end{tabular}

${ }^{1)} \mathrm{CREY}$, Yanggaeng containing roasted coffee ground residue extract; CRPY, Yanggaeng containing roasted coffee ground residue powder.

${ }^{2)}$ Each value was expressed as the mean $\pm \mathrm{SD}(\mathrm{n}=30)$.

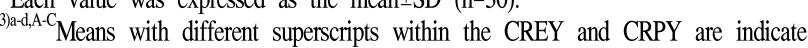
significant differences $(\mathrm{p}<0.05)$.

\section{요 약}

커피박의 식품소재화를 위해 생리활성과 양갱 제조시 활용 가능성을 검토하기 위해 커피박 열수추출물 첨가 양갱 (CREY)와 커피박 분말 첨가 양갱(CREP)를 제조하였다. 커피원두와 커피박 열수 추출물의 총 폴리페놀 함량과 $\mathrm{DPPH}$ 라디칼 소거능은 각각 $13.65 \mu \mathrm{g} / \mathrm{mL}$ 와 $78.75 \%$ 를 나타내었다. $\mathrm{pH}$ 는 대조구가 7.42, $\mathrm{CREY}$ 는 7.10 7.29의 범 위를 나타내었고, CRPY는 6.95 7.15의 범위를 나타내었다. $\mathrm{CREY}$ 의 수분 함량은 37.88 38.92\%, CRPY는 39.3 40.0\% 의 범위로 대조구(36.34\%)보다 높은 수분함량을 나타내었 다. 당 함량은 대조구가 가장 높았다. 총 폴리페놀 함량은 CREY가 $15.88 \sim 66.19 \mu \mathrm{g} / \mathrm{mL}, \mathrm{CRPY}$ 는 12.09 23.80 $\mathrm{\mu g} / \mathrm{mL}$ 의 범위를 나타내어 $\mathrm{CRE}$ 와 $\mathrm{CRP}$ 의 첨가농도 $(0.1,0.3,0.5$ 및 $1.0 \%)$ 에 따라 유의적으로 증가하였다 $(\mathrm{p}<0.05) . \mathrm{DPPH}$ 라디칼 소거능은 대조구가 $1.88 \%, \mathrm{CREY}$ 는 $8.77 \sim 3.10 \%$ 로
농도 의존적으로 증가하였으며, CRYP도 5.28 14.92\%의 범위를 나타내어 대조구보다 유의적으로 높았다( $\mathrm{p}<0.05)$. 양갱의 관능검사 결과, 색, 맛과 풍미 모두 $\mathrm{CREY}$ 와 $\mathrm{CRPY}$ 가 대조구에 비해 우수하였으며, 커피박 열수 추출물을 사 용할 경우 $0.5 \%$, 커피박 분말을 사용할 경우 $0.3 \%$ 를 첨가한 양갱이 관능적으로 가장 우수하였다.

\section{References}

1. Rim SH, Zong MS, Park SH (1995) A Study on removal of $\mathrm{Pb}, \mathrm{Cr}, \mathrm{Cd}$ in wastewater using exhausted coffee. Korean J Environ Health Sci, 21, 21-28

2. Lee SB, Kim HJ, Lee JD (2010) Optimum solvent for oil extraction from cellulosic wastes. J Korea Soc Waste Manag, 27, 137-143

3. Sohn KH, Lee MJ, Min SH, Lee HJ (2000) A Study on the factors affecting the consumption of coffee and tea among female in Seoul. J Korean Soc Food Cult, $15,398-412$

4. Silva MA, Nebra SA, Machado Silva MJ, Sanchez CG (1998) The use of biomass residues in the Brazilian soluble coffee industry. Biomass Bioenergy, 14, 457-467

5. Ko YH, Kang SY, Jung IS (2012) Effects of dietary supplementation of coffee meal on growth performance, blood biochemical profiles and antioxidant defense system in broiler chickens. Korean J Poult Sci, 39, 223-232

6. Rhi JW, Shin HS (1996) Physicochemical properties of antioxidant fractions extracted from freeze-dried coffee by various solvents. Korean J Food Sci Technol, 28, 109-116

7. Song EJ, Kim JY, Lee SY, Kim KBWR, Kim SJ, Yoon SY, Lee SJ, Lee CJ, Ahn DH (2009) Effect of roasted ground coffee residue extract on shelf-life and quality of salted mackerel. J Korean Soc Food Sci Nutr, 38, 780-786

8. Yoo KM, Song MR, Jung EJ (2011) Preparation and sensory characteristics of chocolate with added coffee waste. Korean J Food Nutr, 24, 111-116

9. Jung S, Kang WW (2011) Quality characteristics of cookies prepared with flour partly substituted by used coffee grounds. Korean J Food Preserv, 18, 33-38

10. Pyo SJ, Joo NM (2011) Optimization of Yanggaeng processing prepared with mulberry juice. J Korean Soc Food Cult, 26, 283-294

11. Park CH, Kim HK, Yook HS (2014) Free radical 
scavenging ability and quality characteristics of Yanggaeng combined with grape juice. Korean J Food Nutr, 27, 596-602

12. Park SH, Hyun JS, Park JS, Han JH (2004) Characteristics of Yanggaeng with lotus root and Omija. Korean J Orient Physiol Pathol, 18, 1437-1442

13. Choi EJ, Kim SI, Kim SH (2010) Quality characteristics of Yanggaeng by the addition of green tea powder. J East Asian Soc Diet Life, 20, 415-422

14. Park EY, Byun GI (2005) Quality characteristics of pine mushroom Yanggaeng prepared by different addition of frozen pine mushroom according to different pre-treatment. Korean J Food Cult, 20, 738-743

15. Kim JH, Park JH, , Park SD, Kim JK, Kang WW, Moon KD (2002) Effect of addition of various mesh sifted powders from safflower seed on quality characteristic of Yangeng. Korean J Food Preserv, 9, 309-314

16. Park EY, Kang SG, Jeong CH, Choi SD, Shim KH (2009) Quality characteristics of Yanggaeng added with paprika powder. J Agric Life Sci, 43, 37-43

17. Park LY, Woo DI, Lee SW, Kang HM, Lee SH (2014) Quality characteristics of Yanggaeng added with different forms and concentrations of fresh paprika. J Korean Soc Food Sci Nutr, 43, 729-734

18. Singleton VL, Orthofer R, Lamuela-Raventos RM (1999) Analysis of total phenols and other oxidation substrates and antioxidants by means of Folin-Ciocalteu reagent. Method Enzymol, 299, 152-178
19. Blois MS (1958) Antioxidant determinations by the use of a stable free radical. Nature, 181, 1199-1200

20. Kwak ES, Kim HR, Lee KJ, Kim MR (2009) Antioxidant activities and quality characteristics of fermented and aged garlic Yanggeng. Korean J Food Cook Sci, 25, 739-746

21. AOAC (1995) Official Methods of Analysis. 16th ed, Association of Official Analytical Chemists, Washington DC, USA, p 1-26

22. Hwang ES, Lee YJ (2013) Quality characteristics and antioxidant activities of Yanggaeng with aronia juice. J Korean Soc Food Sci Nutr, 42, 1220-1226

23. Niseteo T, Komes D, Belsak-cuitanovic A, Horzic D, Buder M (2012) Bioactive composition and antioxidant potential of different commonly consumed coffee brews affected by their preparation technique and milk addition. Food Chem, 134, 1870-1877

24. Park CH, Kim KH, Kim NY, Kim SH, Yook HS (2014) Antioxidative capacity and quality characteristics of Yanggaeng with fermented aged black giant garlic (Allium ampeloprasum L. var. ampeloprasum auct.) paste. Korean J Food Nutr, 27, 1014-102

25. Kim AJ, Han MR, Lee SJ (2012) Antioxidative capacity and quality characteristics of Yanggaeng using fermented red ginseng for the elderly. Korean J Food Nutr, 25, 83-89

26. Pyun YR, Yu JH, Jeon IS (1978) Studies on the rheological properties of Yanggaeng. Korean J Food Sci Technol, 10, 344-349 